\title{
ХРОНИКА
}

УДК55(092)

\section{К 80-летию профессора Александра Сергеевича Флаасса}

\section{О.Е. Кочнева}

Пермский национальный исследовательский политехнический университет, 614990, Пермь, Комсомольский пр., 29

E-mail: olgakochneva777@ yandex.ru

(Статья поступила в редакиию 30 января 2016 г.)

Приведены сведения о научной, учебной и производственной деятельности профессора А.С. Флаасса.

Ключевые слова: А.С. Флаасс, кафедра геологии нефти и газа ПНИПУ.

DOI: $10.17072 /$ psu.geol.30.100

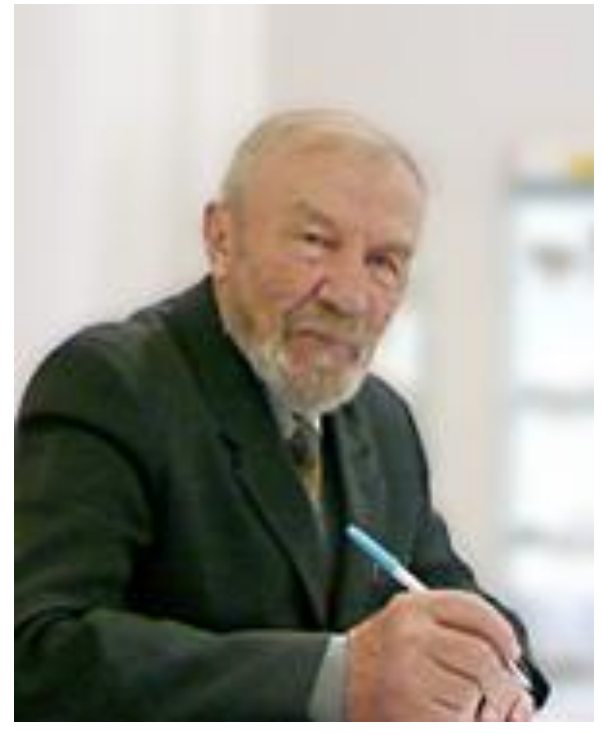

Александр Сергеевич Флаасс родился 12 января 1936 г. в п. Юг Пермской области. В 1954 г. поступил на геологический факультет Пермского государственного университета и в 1959 г. окончил его с отличием по специальности «Поиски и разведка месторождений полезных ископаемых».

В 1959-1961 гг. А.С. Флаасс - геолог Серебрянской геолого-съёмочной партии Съёмочно-тематической экспедиции Пермского геологоразведочного треста Министерства геологии.

С 1961 по 1972 г. работал в МамскоЧуйской комплексной территориальной экспедиции Иркутского геологического управления геологической съёмки в должности геолога, старшего геолога, главного геолога.

В 1972 г. А.С. Флаасс был приглашен член-корреспондентом АН СССР профессором А.С. Хоментовским на должность старшего научного сотрудника кафедры геологии Пермского политехнического института и до 1978 г. являлся ответственным исполнителем хоздоговорных научно-исследовательских тем, после чего перешел на преподавательскую работу [1, $2]$.

В 1975 г. Александр Сергеевич защитил кандидатскую диссертацию «Особенности геологического строения и структурная эволюция Мамской кристаллической полосы».

По направлению Минвуза СССР в течение 6 лет работал в вузах Алжира (19781982 гг. - в Национальном институте нефти, газа и химии; 1986-1988 гг. - в Аннабинском университете). А.С. Флаасс читал лекции на французском языке по дисциплинам «Общая геология», «Структурная геология», «Геотектоника», руководил учебной и производственной практикой студентов и дипломным проектированием [7, 8].

Материалы, полученные в процессе многолетних исследований в Мамской кристаллической полосе в складчатом об- 
рамлении Кузнецкой впадины, на Среднем Урале и в различных районах Северной Африки, легли в основу докторской диссертации «Принципы и методические приемы комплексного структурного анализа складчатых форм в сложнодислоцированных толщах», которая была успешно защищена в 1993 г. в г.С.-Петербурге. Ученое звание профессора ему присвоено в 1995 г.

С 1994 по 1997 г. исполнял обязанности заведующего кафедрой геологии нефти и газа. В течение нескольких лет в должности профессора читал по совместительству курс «Общая геология» в Пермском государственном университете.

Главным направлением научных исследований Александра Сергеевича является структурный анализ сложнодислоцированных комплексов. Им разработаны теоретические основы и методика геодинамического анализа ориентировок макроструктурных тектонических элементов, заложены основы нового направления структурных исследований - анализа закономерностей перераспределения и дифференциации вещества в складчатых структурах.

Им опубликованы два учебных пособия для студентов, аспирантов и специалистов, занимающихся геологической съемкой в сложноскладчатых регионах, две монографии (в соавторстве), учебник по структурной геологии (в соавторстве) и около 80 статей, значительная часть из них - в различных изданиях АН СССР, АН УССР $[3,4]$.

В 2000-2014 гг. помимо преподавательской деятельности А.С. Флаасс занимается научно-исследовательской работой, основная тематика которой посвящена проблеме происхождения и развития локальных структур нефтегазоносных регионов Западной Сибири $[5,6]$.

Много лет он был членом диссертационных советов по присуждению ученых степеней кандидата и доктора наук (в ПГНИУ и ПНИПУ), руководил аспирантами. Длительное время А.С. Флаасс возглавлял Государственную экзаменацион- ную комиссию по геологической специальности в Пермском государственном национальном исследовательском университете.

В период работы в Восточной Сибири он был занесён в Книгу Почёта МамскоЧуйской комплексной территориальной экспедиции, в Книгу Почёта Иркутского территориального геологического управления, награждён медалью «За трудовую доблесть». Имеет нагрудный знак «Почетный работник высшего профессионального образования РФ».

А.С. Флаасс - ветеран труда и за многолетнюю научно-педагогическую работу ему присвоено звание ветерана ПНИПУ.

Александр Сергеевич работал на кафедре геологии нефти и газа Пермского национального исследовательского политехнического университета до 2015 г.

Поздравляем юбиляра и желаем здоровья, счастья и земных благ!

\section{Библиографический список}

1. Флаасс A.C. Некоторые особенности структурного развития Мамско-Бодайбинской серии // Геотектоника. 1971. № 6. С. 5864.

2. Флаасс A.C. Основные этапы и динамика структурного развития мамскободайбинской метаморфической серии (Северо-Байкальское нагорье) // Вопросы геологии Прибайкалья и Забайкалья. Чита, 1971. Вып. 8. С. 33-37.

3. Флаасс А.С. Структурная геология с основами геотектоники. Пермь: Изд-во ПГТУ, $2007.88 \mathrm{c}$

4. Флаас А.С. Геотектоника (методические приемы палеотектонического анализа). Пермь, 2008.197 с.

5. Флаасс А.С. Генезис и динамика формирования локальных поднятий в Среднеобской нефтегазоносной области Западной Сибири // Нефтяное хозяйство. 2012. №5. C.67-72.

6. Флаасс А.С. Анализ складчатых структур. Lambert Academic Publishing. 2013. 188c.

7. Flessa A. Structure de t'écorce terrestre et son év 1u-tion. Algerie: INH, 1982. 65 p.

8. Flessa A. Determination des roches. Algerie: INH, $1988.78 \mathrm{p}$. 


\section{To the 80th Anniversary of Professor Alexander Flaass}

\section{O.E. Kochneva}

Perm National Research Polytechnic University, 29 Komsomolskiy Ave., Perm 614990, Russia. E-mail: olgakochneva777@yandex.ru

The information devoted to $80^{\text {th }}$ anniversary of Professor A. S. Flaass and his scientific, educational, and industry achievements is presented.

Key words: Alexander Flaass, geological survey, Department of the Oil and Gas Geology.

\section{References}

1. Flaass A.S. 1971. Nekotorye osobennosti strukturnogo razvitiya MamskoBodaybinskoy serii [Some peculiarities of structural development of the MamaBodaybo serie]. Geotektonika. 6:58-64. (in Russian)

2. Flaass A.S. 1971. Osnovnye etapy i dinamika strukturnogo razvitiya MamskoBodaybinskoy metamorficheskoy serii (Severo-Baykalskoe nagorie) [Milestones and dynamics of the structural development of the Mama-Bodaybo metamorphic series (North Baykal Highland)]. Voprosy geologii Pribaykalya and Zabaykalya. 8:33-37. (in Russian)

3. Flaass A.S. 2007. Strukturnaya geologiya s osnovami geotektoniki [Structural geology with geotectonics basics]. Perm, Publishing House of the PSTU, p. 88. (in Russian)
4. Flaas A.S. 2008. Geotektonika (metodicheskie priomy paleotektonicheskogo analiza) [Geotectonics (instructional techniques of paleotectonic analysis)]. Perm, p. 197. (in Russian)

5. Flaass A.S. 2012. Genezis i dinamika formirovaniya lokalnykh podnyatiy $\mathrm{v}$ Sredneobskoy neftegazonosnoy oblasti Zapadnoy Sibiri [Genesis and dynamics of the formation of local uplifts in Sredneobskaya oil and gas field in Western Siberia]. Neftyanoe khozyaystvo. 5:67-72. (in Russian)

6. Flaass A.S. 2013. Analiz skladchatykh struktur [Analysis of folded structures]. Lambert Academic Publishing. p. 188. (in Russian)

7. Flessa A. 1982. Structure de t'écorce terrestre et son év 1ution. Algerie, INH, p. 65. (in French)

8. Flessa A. 1988. Determination des roches. Algerie, INH, p.78. (in French) 